\title{
Topical Spray Dosage Form
}

National Cancer Institute

\section{Source}

National Cancer Institute. Topical Spray Dosage Form. NCI Thesaurus. Code C91194.

A spray intended for topical administration. 